\title{
Health potential of female candidates to the professional military service
}

\author{
Alicja Kaiser ${ }^{1}$, Marek Sokołowski ${ }^{2}$ \\ 1 Wielkopolska Higher School of Tourism and Management, Poznań; 2 University School of Physical Education, \\ Poznań, Poland
}

\section{Summary}

Study aim: To assess health and social characteristics of female candidates for professional officers and non-commissioned officers of Polish Army.

Material and methods: All female students of officer and non-commissioned officer Military Academies (16 each) were studied in 2009. Two questionnaires were applied in the study: IPAQ (short) for assessing the level of physical activity of the respondents and a specially designed questionnaire for assessing social situation, perceived health and pro-health behaviours.

Results: The influence of the society on the respondents' decision to join the army is significantly higher among NCOS students than in the group of OS respondents $(\mathrm{p}<0.05)$. OS students perceive their health better than their NCOS mates $(\mathrm{p}<0.05)$. Among students' pro-health behaviours that were assessed in the research, the most advantageously presented is their physical activity. NCOS students are more resilient mentally $(\mathrm{p}<0.01)$, yet their inclination to make use of health service is much lower $(\mathrm{p}<0.01)$.

Conclusions: The modern educational trends in health promotion call for modifying the existing military school curricula by including health education issues so that the superiors acquire not only commanding skills but become also exemplary health educators.

\section{Key words: Female soldiers - Health behaviours - Physical activity}

\section{Introduction}

System changes in Poland, which started in 1989, included armed forces and the participation of women in them. Like in case of men, female subjects in armed forces have to be in good health, be resistant psycho-emotionally and be physically fit. Therefore, those issues have been under a regular monitoring in Poland and in other countries as well $[3,4,8,9,16]$. The health potential of soldiers includes also issues related to the lifestyle, the health behaviours, health-directed training and education are thus the matter of studies $[7,11,15]$. Armed forces are a specific and important community, regarding the educational issues. Armed forces are regarded as a totalitarian organisation, whose community is fairly isolated from the outer population; all daily activities of military community take place in a restricted region under steady supervision. The lifestyle of subordinates depends, to quite an extent, on their superiors and the officers and non-commissioned officers are thus responsible for shaping health behaviours by their educational activities and by setting a good example. The aim of this study was thus to determine the health-related characteristics of female candidates for officers and non-commissioned officers.

\section{Material and Methods}

Two groups of female students of Armoured Land Forces Academies in Wrocław (officer school; OS) and in Poznań (non-commissioned officer school; NCOS), $\mathrm{n}=16$ each, volunteered to participate in the study conducted in 2009. Two questionnaires were applied by hall interviews: IPAQ (short) $[1,2,22]$ for assessing the level of physical activity of the respondents and a specially designed questionnaire for assessing the perceived health and related issues, physical fitness, dietary habits, demographic data, etc. That questionnaire contained 32 items and was validated by a preceding pilot study.

The data were assessed by applying the chi-square function in logarithmic form [19]. The level of $p \leq 0.05$ was considered significant. Whenever no significant differences between groups were noted, the results of both groups combined were shown. 


\section{Results}

The results are presented in Tables $1-7$. All students of officer school had higher education, most of them came from medium-size or big towns and were older than their mates from the NCO school $(\mathrm{p}<0.05)$. No significant differences were found in other demographic variables (Table 1). When interviewed, they were asked about military traditions in their families; most NCOS students had family members in the army or working for the army in contrast to only few OS students who reported having them ( $\mathrm{p}<0.05)$. Only 8 of all 32 subjects had neither relatives nor friends associated with the army.

Table 1. Numbers of female students of military officer schools responding to demographic questions

\begin{tabular}{|c|c|c|}
\hline Variable & $\begin{array}{c}\text { OS } \\
\mathrm{n}=16\end{array}$ & $\begin{array}{l}\text { NCOS } \\
\mathrm{n}=16\end{array}$ \\
\hline Mean age (years) & 28 & 21 \\
\hline BMI & \multicolumn{2}{|c|}{$21.9(18-29)$} \\
\hline \multicolumn{3}{|l|}{ Education of respondents } \\
\hline Secondary & 0 & 9 \\
\hline Higher & 16 & 7 \\
\hline \multicolumn{3}{|l|}{ Mother's education } \\
\hline Primary & \multicolumn{2}{|c|}{3} \\
\hline Vocational & \multicolumn{2}{|c|}{13} \\
\hline Secondary & \multicolumn{2}{|c|}{12} \\
\hline Higher & \multicolumn{2}{|c|}{4} \\
\hline \multicolumn{3}{|l|}{ Father's education } \\
\hline Primary & \multicolumn{2}{|c|}{4} \\
\hline Vocational & \multicolumn{2}{|c|}{14} \\
\hline Secondary & \multicolumn{2}{|c|}{8} \\
\hline Higher & \multicolumn{2}{|c|}{6} \\
\hline \multicolumn{3}{|l|}{ Residence } \\
\hline Village & 3 & 8 \\
\hline Town, up to 10000 inhabitants & \multicolumn{2}{|c|}{1} \\
\hline Town, $10-100000$ inhabitants & \multicolumn{2}{|c|}{9} \\
\hline Town, above 100000 inhabitants & 8 & 3 \\
\hline \multicolumn{3}{|l|}{ Economic status } \\
\hline Very good & \multicolumn{2}{|c|}{3} \\
\hline Good & \multicolumn{2}{|c|}{19} \\
\hline Moderate & \multicolumn{2}{|c|}{10} \\
\hline $\mathrm{Bad}$ & \multicolumn{2}{|c|}{0} \\
\hline Family members in the army & 6 & 12 \\
\hline
\end{tabular}

Legend: OS - Officer school; NCOS - Non-commissioned officer school; The numbers were reported for each school separately only when significantly different $(\mathrm{p}<0.05)$

The OS students rated their health status significantly $(p<0.05)$ higher than their NCOS mates. No significant between-group differences were found with respect to the perceived physical fitness or to the engagement in physical activities as determined by IPAQ questionnaires (Table 2). The motives of undertaking motor activities are presented in Table 3. The predominant reason for practicing motor activities was keeping fit. It should be noted that OS students declared health maintaining/improving significantly $(\mathrm{p}<0.05)$ more frequently than their NCOS mates, the latter ones indicating also relaxing from stress, not mentioned by any OS subject.

Table 2. Perceived health and physical fitness of female students of military officer schools

\begin{tabular}{lcc}
\hline Variable & $\begin{array}{c}\text { OS } \\
\mathrm{n}=16\end{array}$ & $\begin{array}{c}\text { NCOS } \\
\mathrm{n}=16\end{array}$ \\
\hline Perceived health & \multicolumn{2}{c}{5} \\
Very good & 5 & 11 \\
$\quad$ Good & \multicolumn{2}{c}{} \\
Perceived fitness & \multicolumn{2}{c}{19} \\
Very good & \multicolumn{2}{c}{10} \\
Good & \multicolumn{2}{c}{3} \\
Moderate & \multicolumn{2}{|c}{} \\
Physical activity by IPAQ & \multicolumn{2}{c}{15} \\
High & \multicolumn{2}{c}{14} \\
Sufficient & \multicolumn{2}{c}{3} \\
Insufficient & \multicolumn{2}{c}{} \\
\hline
\end{tabular}

For explanations see Table 1

Table 3. Numbers of female students of military officer schools responding to questions related to motives of undertaking motor activities (multiple choice answers)

\begin{tabular}{|c|c|c|}
\hline Motivation & $\begin{array}{c}\text { OS } \\
\mathrm{n}=16\end{array}$ & $\begin{array}{l}\text { NCOS } \\
\mathrm{n}=16\end{array}$ \\
\hline Keeping fit & \multicolumn{2}{|c|}{22} \\
\hline Relaxing from stress & 0 & 7 \\
\hline Pleasant leisure & \multicolumn{2}{|c|}{6} \\
\hline Good results in fitness tests & \multicolumn{2}{|c|}{15} \\
\hline Attractive body shape & \multicolumn{2}{|c|}{5} \\
\hline Health maintaining/improving & 9 & 3 \\
\hline Fashion & \multicolumn{2}{|c|}{3} \\
\hline
\end{tabular}

For explanations see Table 1

As follows from Table 4, motor activities were not the dominant form of leisure activities. No between-group differences were noted in various leisure activities with one exception: significantly $(\mathrm{p}<0.05)$ more OS students declared reading books and magazines compared with their ONCS mates.

Some questions pertained to the mode of nutrition. No significant between-group differences were found regarding the numbers of meals consumed daily; overall, 
13 subjects declared having more than 3 meals a day, 16 - having 3 meals and only 3 had less than 3 meals. The declared frequencies of consuming various food products are presented in Table 5. Among the beneficial dietary habits were frequent consumptions of fruit and vegetables, dominance of poultry over beef/pork meat, dairy products, drinking mineral water every day and avoiding sweet beverages. Among the unfavourable ones were very low consumption of fish, low consumption of wholemeal bread (mainly OS subjects; $\mathrm{p}<0.05$ ), too high a consumption of animal fats and frequent consumption of sweets.

Table 4. Numbers of female students of military officer schools responding to questions related to the forms of leisure activities (multiple choice answers)

\begin{tabular}{lcc}
\hline Forms of leisure activities & OS & NCOS \\
& $\mathrm{n}=16$ & $\mathrm{n}=16$ \\
\hline Hobbies & \multicolumn{3}{c}{16} \\
Meeting friends & \multicolumn{2}{c}{13} \\
Various motor activities & \multicolumn{2}{c}{10} \\
Sleeping & \multicolumn{2}{c}{5} \\
Reading books, magazines & 8 & \multicolumn{2}{c}{3} \\
Computer, TV-watching & \multicolumn{3}{c}{3} \\
\hline
\end{tabular}

For explanations see Table 1

Table 5. Consumption of various food products (mean numbers of days per week) as declared by female students of military officer schools

\begin{tabular}{|c|c|c|}
\hline Product & $\begin{array}{c}\text { OS } \\
\mathrm{n}=16\end{array}$ & $\begin{array}{l}\text { NCOS } \\
n=16\end{array}$ \\
\hline Milk & \multicolumn{2}{|c|}{3.3} \\
\hline Milk products & \multicolumn{2}{|c|}{3.3} \\
\hline Plant fats & 3.6 & 2.2 \\
\hline Animal fats & \multicolumn{2}{|c|}{3.7} \\
\hline White bread & 5.3 & 4.3 \\
\hline Wholemeal bread & 1.8 & 2.4 \\
\hline Cured pork meat & 3.3 & 2.3 \\
\hline Cured poultry meat & \multicolumn{2}{|c|}{2.8} \\
\hline Beef meat & 2.0 & 2.7 \\
\hline Poultry & \multicolumn{2}{|c|}{3.3} \\
\hline Fish & \multicolumn{2}{|c|}{1.1} \\
\hline Potatoes & \multicolumn{2}{|c|}{4.4} \\
\hline Grains, rice & \multicolumn{2}{|c|}{1.7} \\
\hline Leguminous plants & \multicolumn{2}{|c|}{4.4} \\
\hline Vegetables, salads & \multicolumn{2}{|c|}{5.9} \\
\hline Fruit & 1.9 & 1.5 \\
\hline Fruit/vegetable juice & \multicolumn{2}{|c|}{4.8} \\
\hline Mineral water & \multicolumn{2}{|c|}{4.3} \\
\hline Coca-cola, Pepsi, Fanta, etc. & \multicolumn{2}{|c|}{6.6} \\
\hline Sweets & \multicolumn{2}{|c|}{1.1} \\
\hline
\end{tabular}

For explanations see Table 1
When asked about the use of stimulants, 23 out of 32 subjects declared being non-smokers, 17 of which used to smoke but were no addicts. The smokers declared smoking about 10 cigarettes a day for at least 8 years. Also 23 subjects used alcoholic beverages only occasionally and in small quantities, 3 subjects - regularly or in larger quantities, the other ones abstained from alcohol altogether.

The NCOS students exhibited much higher $(\mathrm{p}<0.01)$ psycho-emotional resistance than their OS mates (Table 6). The most common ways to cope with an increased nervousness were meeting friends, next motor activities, shopping or visiting cinema. No subject mentioned being helpless or taking medicines in stressful situations. On the other hand, the NCOS students cared less for their health compared with their OS mates (Table 7) - more of them ignored symptoms of health disorders and only less than half of them declared performing preventive examinations $(p<0.01)$. With respect to other ways of dealing with health disorders mentioned in Table 7 , or to visiting dentists both when needed or for preventive reasons, no between-group differences were noted.

Table 6. Incidence of increased nervousness as declared by female students of military officer schools

\begin{tabular}{lcc}
\hline Frequency & $\begin{array}{c}\text { OS } \\
\mathrm{n}=16\end{array}$ & $\begin{array}{c}\text { NCOS } \\
\mathrm{n}=16\end{array}$ \\
\hline Seldom or at times & 7 & 14 \\
Frequently & 9 & 2 \\
\hline
\end{tabular}

$\mathrm{p}<0.01$; For other explanations see Table 1

Table 7. Managing various health disorders and the necessity of prophylaxis as declared by female students of military officer schools

\begin{tabular}{lccc}
\hline Response & OS & NCOS \\
& $\mathrm{n}=16$ & $\mathrm{n}=16$ \\
\hline Ignoring them & 3 & & 8 \\
Self-administered therapy & & 11 & \\
Seeking advice in the web & & 11 & \\
Going by friends' advice & \multicolumn{2}{c}{9} & \\
Visiting the physician & & 10 & \\
Preventive examinations & 14 & & 7 \\
\hline
\end{tabular}

For explanations see Table 1

\section{Discussion}

When analysing the social and educational factors associated with the female students of an officer school and a non-commissioned officer school, some significant differences could be detected. All OS students had higher education in contrast to about half of the NCOS students; moreover, more OS students resided in big towns and less 
in villages compared with the NCOS ones. The latter had also a stronger family background regarding military activities and traditions.

When assessing health attitudes of the female soldiers, the current principles of health promotion and specificity of the military environment as a total institution had to be considered. Thus, women who wanted to meet the requirements of military service had to strengthen their health potential by adjusting their health behaviours; the presented data show they managed that task. Among the health behaviours, the engagement of all the subjects studied in motor activities was remarkable compared with the Polish population. The level of physical activity as determined by IPAQ was comparable to that reported by other authors for military communities $[6,12,13,17]$ or for physical education female students [18]. However, some behaviours ought to be modified, like e.g. shaping preventive attitudes, especially among the NCOS students who often neglected them. This tallies with the effects of longitudinal observations in student communities, although female students were superior in that respect to the male ones $[14,20]$. On the other hand, OS students proved inferior to their NCOS mates with respect to managing stressful situations. Problems in that respect were also reported for university female students in Poland and abroad [5,10,21]. Inasmuch physical education curricula contain a number of health-directed activities introduced in Poland in 2009, no obligatory classes in health education and promotion exist in officer or NC-officer schools for land forces. The presented results are thus pointing to the indispensability of adjusting the existing curricula. Physical education in military schools aims at shaping a high physical fitness but its educational role ought to be expanded and include the health-directed issues to a greater extent.

Army, as a total institution, offers both benefits and drawbacks with regards to the modern health education. Since the lifestyle of subordinates depends largely on the attitudes and behaviour of their superiors, the latter may positively or negatively affect the health behaviours of the subordinates. Since health education is an interactive process, the "order-execution" principle ought to be replaced by partnership to the necessary extent, i.e. the superior should create conditions for making health-directed choices. In conclusion, the modern educational trends in health promotion call for modifying the existing military school curricula by including health education issues so that the superiors acquire not only commanding skills but become also exemplary health educators.

\section{References}

1. Biernat E., R.Stupnicki (2005) An overview of internationally applicable questionnaires designed for assessing physical activity. Phys.Edu.Sport, 49:32-42.
2. Craig C.L., A.L.Marshall, M.Sjöström, A.E.Bauman, M.L.Booth, B.E.Ainsworth, M.Pratt, U.Ekelund, A.Yngve, J.F.Sallis, P.Oja (2003) International physical activity questionnaire: 12-country reliability and validity. Med.Sci.Sports Exerc., 35(8):1381-1395.

3. Dyrstad S.M., R.Soltvedt, J.Halle (2006) Physical fitness and physical training during Norwegian military service. Mil.Med., 171:736-741.

4. Faff J., P.Satora, K.Stasiak (2002) Changes in the aerobic and anaerobic capacities of army recruits during their military training are related to the initial level of physical fitness of the subjects. Biol.Sport., 19:251-265.

5. Hermon D.A., G.Davis (2004) College student wellness: a comparison between traditional and nontraditional age students. J.Coll.Counsel., 7: 32-39.

6. Kaiser A., M.Sokołowski, (2009). Health and social issues of women in the army. In: M.Sokołowski (ed.) Contemporary tasks, problems and perspectives of physical education in the army, Polish Scientific Physical Education Association Section of Physical Education in the Army, Warsaw, pp. 313-322.

7. Kalina R.M., B.J.Barczyński (2009) Permanent healthrelated training of regular soldiers - conditions and assumptions. In: M.Sokołowski (ed.) Contemporary tasks, problems and perspectives of physical education in the army. Polish Scientific Physical Education Association Section of Physical Education in the Army, Warsaw, pp. 323-331.

8. Klukowski K., K.Mazurek (2007) Physical performance of women in the light of military service requirements. In: M.Sokołowski (ed.) Biosocial effects of military service as a basis for further improvement of future physical education and sports programmes. Wyd. AWF Poznań, pp. 67-74.

9. Knapik J.J., M.A.Sharp, S.Darakjy, S.B.Jones, K.G. Hauret, B.H.Jones, (2006) Temporal changes in the physical fitness of US Army recruits. Sports Med., 36(7): 613-634.

10. LaFountaine J, M.Neisen, R.Parsons (2006) Wellness factors in first year college students. American J.Health Stud.,21 (4): 214-218.

11. Laudańska-Krzemińska I., A.Kaiser (2009) Lifestyle of regular army applicants - a difficult beginning or a good start? In: M.Sokołowski (ed.) Contemporary tasks, problems and perspectives of physical education in the army. Polish Scientific Physical Education Association Section of Physical Education in the Army, Warsaw, pp. 323-331.

12. Lenart D. (2010) Physical activity vs. morpho-functional development of women (english abstract). In: J.Łuczak, S.Bronowicki (eds.) Zdrowotne aspekty aktywności fizycznej Wyd. Wielkopolska Wyższa Szkoła Turystyki i Zarządzania w Poznaniu, Poznań, pp. 245-253.

13. Mierzejewski, R. (2008) Evaluation of the level of the land forces solders' physical activity on the base of the International Physical Activity Questionnaire (IPAQ) (english abstract). In: E.Szczepanowska, M.Sokołowski (eds.) Aktywność fizyczna i odżywianie się jako uwarunkowania promocji zdrowia Wyd. Wielkopolska Wyższa Szkoła Turystyki i Zarządzania w Poznaniu, Poznań, pp. 225-232.

14. Popay J., M.Bartley, I.Plewis (1992) Gender Inequalities in Health: Social Position, Affective Disorders and Minor Physical Morbidity. Soc.Sci.Med., 36 (1): 21-32.

15. Rasińska R., M.D.Głowacka, A.Głowacka-Rębała (2011) Educational determinants in shaping soldiers' health attitudes. In: A.Kaiser, A.Tomczak (eds.), Physical activity and health promotion in the military environment. Polish Scientific Physical Education Association Section of Physical Education in the Army, Warsaw, pp.235-246. 
16. Sokołowski M. (2004) Type of body build and motor ability of candidates for professional military sevice. Ceska Antropologie, 54:183-184.

17. Sokołowski, M., M.Mrozkowiak, A.Kaiser (2009) International physical activity questionnaire (IPAQ) as a tool to assess the potential regular soldiers. In: M.Sokołowski (ed.) Contemporary tasks, problems and perspectives of physical education in the army. Polish Scientific Physical Education Association Section of Physical Education in the Army, Warsaw, pp. 349-355.

18. Sokołowski M., A.Kaiser, A.Cepulenas (2010) Physical activity of female students of the University School of Physical Education in Poznan on the basis of IPAQ- educational and social perspectives. Ugdymas Kuno Kultura Sportas, 3:90-95.

19. Stupnicki R. (2008) Analysis and Presentation of Questionnaire Data. University of Physical Education Editions, Warsaw.
20. Verbrugge L.M. (1985) Gender and Health: An update on hypotheses and evidence. J.Health Soc.Behav., 26 (3):156-182.

21. Von Bothmer M.I., B.Fridlund (2005) Gender differences in health habits and in motivation for healthy lifestyle among Swedish university students. Nurs.Health.Sci. 7(2):107-18.

22. www.ipaq.ki.se/downloads.htm.

Received 20.10 .2010
Accepted

(C) University of Physical Education, Warsaw, Poland 